\title{
An Analysis of English Reading Comprehension Problems Faced By Students of Education at Graduate Level
}

\author{
${ }^{1}$ Sehrish Javed, ${ }^{2}$ Saira Maqbool
}

\begin{abstract}
The paper analyses reading comprehension problems of the graduate students from the discipline of Education at the International Islamic university, Islamabad and Allama Iqbal Open University, Islamabad. The researcher has made an attempt to scientifically investigate whether these students can comprehend the text related to their field in English language or not. The researcher has also tried to find out the problems that these students face while reading some text for comprehension. The findings unveil the real picture of the students' level of understanding the text at the graduate level. In this study two universities from Islamabad capital territory were selected based on convenient sampling.60 graduate students' reading performance was investigated. To execute the research a comprehension test based on one topic in conjunction with short answers was administered to the graduate level students in both the universities. A questionnaire was also given to the students asking them questions about the problems they face in comprehending a text and the reasons for these problems. The collected data were analyzed through percentage. Data analysis of the test revealed that many of the respondents' comprehension level was weak however, only few respondents were successful in handling the intensive reading tasks. The questionnaires' analysis points out some important issues which are responsible for this lack of comprehension.
\end{abstract}

Keywords: Reading competencies, reading performance, EFL and ESL context

\section{Introduction}

It is a fact that the ruling language is always of developed countries and as far as Pakistan is concerned we Pakistani belong to a developing country, so we must follow the language i.e. English. We can see around us that someone having no command on English language faces too many problems at every stage of life. We can say that English is the most important language in Pakistan. Since 1947 English has been playing vital role in the field of education. Entire higher

1 MS scholar, Department of Education, International Islamic University, Islamabad Email: s_javed14@yahoo.com

2 Assistant Professor, Department of TEFL, Allama Iqbal Open University, Islamabad Email: sana.sana98@yahoo.com 
education is given in English and if people do not understand then they will not been able to comprehend English language. It is understood that reading and understanding English for education student is momentous in the light of current academic needs and future professional needs. Most of the students of education face problems in reading/understanding the original versions of the texts, because of this reason they try to avoid the original text and take help from the short routes. They are actually required to develop grip over the following skills:

1. Drawing inferences about the meanings of the words from context

2. Finding the answers of questions answered implicitly in the text

3. Drawing inferences of phrases/sentences from the context

4. Identifying writer's thoughts/ideas

5. Following the structure of passage

\subsection{Research Objectives}

The objective of this research included to find out the extent to which the students can comprehend English language and to find out reasons of the problems faced by them.

\subsection{Research Questions}

Following research questions were made keeping in view objectives of study;

1. What is the students' comprehension level of English language?

2. What is the reason of the possible low comprehension level?

3. Can students draw inferences about the meanings of the words from context?

4. Can students find the answers of questions answered implicitly in the text?

5. Can graduate level students draw inferences of phrases/sentences from the context?

6. Can students identify writer's thoughts/ideas?

7. Can students follow the structure of passage correctly?

\subsection{Significance of the Study}

The current research could be useful for teachers in order to improve the reading, skimming and scanning skills of the students. It will be helpful for the teachers in understanding their students' reading problems and will also guide them regarding teaching in an appropriate way.

\section{Literature Review}

Students face a number of problems regarding English reading comprehension. The problems are mostly related to knowledge related to 
background, culture, text type; where background knowledge is prior knowledge of students and if the prior knowledge of student is weak then he will not been able to understand text easily. Background knowledge helps students in creation of new knowledge. Another obstacle is related to cultural differences which affects reading comprehension of the students. Lacking in vocabulary also creates problem in reading because students cannot understand the text if they have less vocabulary. Moreover, if the students do not know about the type of text then he will not been able to understand it; in other words it can be said that student will understand text if he is familiar with text type (Alderson, 2002).

For helping students in understanding text vocabulary plays vital role. The complex material of text books can be understood easily if the student has a good collection of vocabulary items (Hayes, 1991). In terms of vocabulary, the problem is involved with the bank of difficult words for instance synonyms, antonyms, words having multiple meanings, etc. (Graves \& Ryder, 1998).

Ashraf and Ahmad (2003) discovered the main obstacle encountered by most students of ESL was word difficulty. So, it can be said that in reading comprehension, word difficulty is major obstacle faced by ESL learners as they could not understand the meaning of the words without understanding the meaning of difficult words. Understanding of long and complex sentences also creates problem for English as a second language learners in understanding of the proper meaning of sentences. Complex sentences are type of difficult sentences which possess many clauses.

Complex sentences also contain cohesive words like because, thus, however, although, etc. (Aebersold \& Field, 1997). Moreover, complex noun groups, conjunctions, prepositional phrases are mainly cause problem for reading comprehension of the students the reason is that they present complex text which makes it difficult to understand (Nuttall, 2000).

Mostly, English language learner faces inconvenience in reading and understanding English text. The main reason is that limited understanding of sentence construction and limited number of vocabulary creates problem (Gunning, 2002). Furthermore, Chuenta (2002) exposed that this problem is due to inability in grapping main idea and it is because of limited vocabulary items, lack of appropriate reading strategy and inability to write summary.

Eskeys (1986) found that there is a strong relationship between reading comprehension and speed reading. In fact reading comprehension and speed reading are related since a good reader by definition "reads fast (Ghizan, 2012). American students' comprehension levels impact their success in solving mathematical word problems in Arabic or in English (Sarmini, 2009). Another most frequent difficulty that young immigrant's learner face with academic 
literacy across the classroom is academic reading comprehension. There were several challenges the students faced in developing their reading comprehension. One was lack of familiarity with printed text in both English and their local language (Keengwe, 2013).

Perhaps studies on the reading strategies used by the learners in understanding literary texts can help teachers in finding ways to promote understanding and overcome reading comprehension problems especially amongst the low achievement students (Shafaei \& Nejati, 2009). With respect to the less proficient bilingual readers, they continued to demonstrate the ability to monitor comprehension but lack the strategy to use to resolve comprehension problems (Israel \& Duffy, 2014).

The problem associated with under-prepared students are faced to some extent by all colleges and universities who offer developmental courses but more often by community colleges because they offer students an open admission policy (Mc Lendon, 2008).

Poor word-level reading is one of the most common reasons because of which students struggle in reading comprehension (Kilpatrick, 2015). According to Lankamp (1988) English reading proficiency is linked to learners' knowledge of the subject matter dealt within the text (Lankamp, 1988). Additionally the students who are taught through traditional reading instructions are not likely to improve their reading strategy since they do not receive any instruction on strategies which, in turn, lead to their unfamiliarity of reading strategies and finally inability to use them in reading comprehension tasks (Lulu, 2014). A more interactive way of providing students with the main points of reading text is to answer simple multiple choice or true/false comprehension questions based on the texts (Lockyer, 2008).

\section{Methodology}

It was a quantitative study based on exploratory research which aimed at exploring the cause of any phenomenon. It does not aim at finding out or providing final or certain answer of any phenomena but it simply explores the reason and solution of research questions (Singh, 2007). The purpose of this research was to explore the competence level of graduate level students of education in the light of the following sub-skills:

1. Drawing inferences about the meanings of the words from context.

2. Finding the answers of questions answered implicitly in the text

3. Drawing inferences of phrases/sentences from the context

4. Identifying writer's thoughts/ideas.

5. Following the structure of passage. 


\subsection{Research Tools:}

\section{Administration of test}

When the sub-skills were decided the second step for the researcher was to select the tool for research. The purpose of the tool was to analyse the sub-skills mentioned above of the genre of education from the target sample. Once this was done, marks were allocated for these questions. Each question was allocated 10 marks which mean that the total marks of the test were 50. As a new step, clear instructions were written and test time was decided. With consultations in the field of ELT and "Subject Specialist" along with consideration of the size of the text, it was decided that the test would be of 40 minutes duration. Text size and level of difficulty were also one of the major considerations in determining the test time. Lastly, formatting and proof reading was done carefully.

\subsection{Making test scripts}

The scores for each question were transformed into four categories which were as follows:

a) Excellent: $80 \%$ \& above (comprehension level)

b) Good: $60 \%$ to $79 \%$ (comprehension level)

c) Fair: $50 \%$ to $59 \%$ (comprehension level)

d) Poor: below 50\% (comprehension level)

\subsection{Administration of Questionnaire}

After the test the same sample was given questionnaire to check their interest, difficulties and competence level of the students.

\subsection{Population}

All the graduate level students, studying Education in the universities located in Islamabad.

\subsection{Sample}

In this study students from International Islamic university, Islamabad and Allama Iqbal Open University, Islamabad were selected. Students of $7^{\text {th }}$ semester B.S Education and M.A $4^{\text {th }}$ semester constituted the sample; wherein there were total 60 students, $n=60$. Amongst them, 20 were male and 40 female students

\subsection{Data Collection}

The data were collected by the researcher personally.

\subsection{Data Analysis}

Data were analyzed quantitatively. Test scores were converted into the categories: Excellent, Good, Fair, Poor for each question, the score was shifted on a sheet. Against each score, its category was written, i.e. Excellent, Good, Fair, Poor. These scores were then shifted into Tables for each question. In the 
tables, there were columns in which the categories, number of subjects, the specific question and percentages, etc were given.

Findings of the study are presented below;

\section{Findings:}

\section{Drawing inferences about the meanings of the words from context}

Here the question statement was:

Infer the meanings of the underline words with reference to given text. Domain, Cognitive, Taxonomy, Compilation, Hierarchies

Out of 60 students $85 \%$ revealed that their performance was poor. On the other hand those students who revealed that their comprehension was excellent, good or fair were $6 \%, 4 \%$ and $5 \%$ respectively. This shows that a vast majority has poor reading comprehension of education text with reference to finding the rule.

Table 1: Inferences about the Meanings

\begin{tabular}{c|ccc}
\hline Excellent & Good & Fair & Poor \\
\hline $6 \%$ & $4 \%$ & $5 \%$ & $85 \%$ \\
\hline
\end{tabular}

\section{Finding the answers of question implicitly in the text}

Here the research question was:

Is rote learning a better technique for memorizing facts and figures?

The data analysis contained the information that $68 \%$ students were poor in reading comprehension with reference to finding the answers of questions answered implicitly in the text. On the other hand those students who revealed that their excellent, good or fair comprehension were $6 \%, 4 \%$ and $5 \%$ respectively. Once again majority was poor in their comprehension.

Table 2: Implicit Answers of Questions

\begin{tabular}{c|ccc}
\hline Excellent & Good & Fair & Poor \\
\hline $4 \%$ & $13 \%$ & $15 \%$ & $68 \%$ \\
\hline
\end{tabular}

\section{Drawing inferences of phrases/sentences from the context}

With this regard the research question was: Write in one sentence the theme of the text

Out of 60 students $70 \%$ revealed that their performance was poor. On the other hand those students who revealed that their comprehension was excellent, good or fair were $5 \%, 10 \%$ and $15 \%$ respectively. This shows that a vast majority has poor reading comprehension of education text with reference to finding the rule. 
Table 3: Inferences of Phrases/Sentences

\begin{tabular}{c|ccc}
\hline Excellent & Good & Fair & Poor \\
\hline $5 \%$ & $10 \%$ & $15 \%$ & $70 \%$ \\
\hline
\end{tabular}

\section{Identifying writer's thoughts/ideas.}

Here the research question was:

Infer this statement: "Domains may be thought of as categories"

The data showed that $60 \%$ students were poor in comprehension in the context of identifying writer's thought/ idea. On the other hand $13 \%$ were fair, $16 \%$ were good and $11 \%$ were excellent with reference to this skill.

Table 4: Identifying Writer's Thoughts/Ideas

\begin{tabular}{c|ccc}
\hline Excellent & Good & Fair & Poor \\
\hline $11 \%$ & $16 \%$ & $13 \%$ & $60 \%$ \\
\hline
\end{tabular}

\section{Following the structure of passage}

As far as this sub-skill is concerned, the research question was:

Haphazard ideas scatter our mind/concepts. Do you find any haphazard idea/thought in this context? if yes please point it down;

While following the structure of the passage, the students revealed that 55\% of them were poor, $17 \%$ were fair, $13 \%$ were good and $15 \%$ were excellent. Table 5: The Structure of Passage

\begin{tabular}{c|ccc}
\hline Excellent & Good & Fair & Poor \\
\hline $15 \%$ & $13 \%$ & $17 \%$ & $55 \%$ \\
\hline
\end{tabular}

\section{Questionnaire Analysis}

\begin{tabular}{l|llll}
\hline \multicolumn{1}{c|}{ Question } & I feel fine & $\begin{array}{l}\text { I feel that } \\
\text { I could } \\
\text { have done } \\
\text { better }\end{array}$ & $\begin{array}{l}\text { I feel } \\
\text { that I } \\
\text { needed } \\
\text { more } \\
\text { time }\end{array}$ & $\begin{array}{l}\text { I don't } \\
\text { think } \\
\text { about the } \\
\text { test when } \\
\text { I finish it }\end{array}$ \\
\hline $\begin{array}{l}\text { What happens after a reading } \\
\text { comprehension test } \\
\text { (unseen)? }\end{array}$ & 5 & 5 & 35 & 15 \\
\hline
\end{tabular}

The results for this question show that the students are weak in understanding English as 35 students wanted more time for understanding the text. 15 students didn't even bother for the correct results while 15 said that they could do better than what they have done. Only 5 students feel fine. 
Volume II- Issue II (December 2016)

\begin{tabular}{l|llll}
\hline Question & $\begin{array}{l}\text { Because } \\
\text { English is } \\
\text { very } \\
\text { important } \\
\text { subject }\end{array}$ & $\begin{array}{l}\text { Because } \\
\text { my } \\
\text { parents } \\
\text { expect } \\
\text { me to do } \\
\text { well }\end{array}$ & $\begin{array}{l}\text { Because it } \\
\text { shows my } \\
\text { knowledge } \\
\text { of English }\end{array}$ & $\begin{array}{l}\text { I don't } \\
\text { think it } \\
\text { shows my } \\
\text { knowledge } \\
\text { of English }\end{array}$ \\
\hline $\begin{array}{l}\text { It's important to do well on reading } \\
\text { comprehension (unseen) tests in }\end{array}$ & 22 & 18 & 15 & 5 \\
\hline English & & & & \\
\hline
\end{tabular}

Through this question we came to know that only 22 students agree that it's important to do well on reading comprehension (unseen) tests in English because it's an important subject while 18 agree with the reason that their parents expect them to do well, 15 students agree on the reason that it shows their knowledge of English and 5 agree with the reason that it don't show my knowledge of English.

\begin{tabular}{l|llll}
\hline Question & $\begin{array}{l}\text { Ijust } \\
\text { give } \\
\text { up }\end{array}$ & $\begin{array}{l}\text { I usually give } \\
\text { up but } \\
\text { occasionally } \\
\text { try strategies }\end{array}$ & $\begin{array}{l}\text { Ifeel I usually } \\
\text { use strategies } \\
\text { but } \\
\text { occasionally } \\
\text { have to give } \\
\text { up }\end{array}$ & $\begin{array}{l}\text { I always } \\
\text { use } \\
\text { strategies } \\
\text { and rarely } \\
\text { have to } \\
\text { give up }\end{array}$ \\
\hline $\begin{array}{l}\text { When you find any written } \\
\text { information difficult to understand, do } \\
\text { you just give up or do you use } \\
\text { strategies to help you understand? }\end{array}$ & 14 & 33 & 10 & 3 \\
\hline
\end{tabular}

When students were asked to response on what they do when they find any difficult written information 14 students replied that they just give up because they either don't know the strategies to apply for the ease or they or they don't know when and how to apply the strategies, 33 said that they usually give up but occasionally try strategies, 10 said that they usually try strategies but occasionally give up and only 3 said that they always use strategies and rarely they have to give up.

\begin{tabular}{l|llll}
\hline Question & Agree & Neutral & Not sure & Disagree \\
\hline $\begin{array}{l}\text { Reading strategies like stress } \\
\text { management/relaxing exercise would } \\
\text { improve reading comprehension in English? }\end{array}$ & 24 & 15 & 18 & 3 \\
$\begin{array}{l}\text { Proper guidance was not given to me on how } \\
\text { to tackle the reading comprehension? }\end{array}$ & 29 & 11 & 16 & 4 \\
\hline
\end{tabular}


My brain does not see anything that is in

18

22

14

6 front of my eyes immediately.

Then the students were asked to scale the questions accordingly, firstly they were asked a question on which 24 agreed that reading strategies like stress management/ relaxing exercises would improve their reading comprehension in English, 15 gave neutral response, 18 were not sure about it and 3 disagreed. In the reply of second question 29 agreed that proper guidance was not given to them on how to handle the reading comprehension, 11 reasoned as neutral, 18 were not sure and 4 disagreed. Then in third question 18 agreed that they cannot immediately see anything that is in front of their eyes, 22 were neutral, 14 were not sure and 6 disagreed.

\begin{tabular}{|c|c|c|c|c|}
\hline Questions & Always & Usually & Rarely & Never \\
\hline $\begin{array}{l}\text { When you read do you try to see the pictures in } \\
\text { your head? }\end{array}$ & 3 & 9 & 36 & 12 \\
\hline $\begin{array}{l}\text { When you read do you relate/ make a link to } \\
\text { similar things you have read before? }\end{array}$ & 2 & 11 & 32 & 15 \\
\hline Do you ask yourself questions during the reading? & 6 & 17 & 24 & 13 \\
\hline $\begin{array}{l}\text { I face spelling and pronunciation problems in } \\
\text { reading }\end{array}$ & 19 & 29 & 9 & 3 \\
\hline I can understand the thought of the writer easily & 3 & 11 & 31 & 10 \\
\hline I can scan the general idea of the text easily & 2 & 11 & 32 & 10 \\
\hline $\begin{array}{l}\text { We can improve the vocabulary by additional } \\
\text { reading? }\end{array}$ & 11 & 35 & 13 & 1 \\
\hline $\begin{array}{l}\text { Are you able to express yourself in written } \\
\text { language? }\end{array}$ & 2 & 11 & 32 & 10 \\
\hline Do you write answers grammatically correct? & 3 & 13 & 29 & 10 \\
\hline $\begin{array}{l}\text { Can you guess/ predict the meanings of unknown } \\
\text { words with reference to the context? }\end{array}$ & 8 & 24 & 21 & 7 \\
\hline $\begin{array}{l}\text { Do you find many difficult words while doing a } \\
\text { comprehension exercise? }\end{array}$ & 31 & 19 & 7 & 3 \\
\hline
\end{tabular}

In the response of different questions students replied like 3 agreed that they try to imagine the picture of the text they study, 9 said they usually, 36 said rarely and 12 said they never imagine. Then in the response of second question 2 
students said that they always relate/make a link to similar things they read before, 11 said they usually do so, 32 said they rarely do and 15 said that they never do. In the response of next question 6 students said that they always ask questions from themselves during the reading, 17 said they usually ask questions, 24 said that they rarely ask questions and 13 said that they never ask. Next 19 students said that they always face spelling and pronunciation problems in reading while 29 said that they usually face, 9 said that they rarely face while 3 said that they never face such problems. Next 3 said that they always understand the thought of the writer easily, 11 said that they usually understand, 31 said that they rarely understand while 10 said that they never understand the thought of the writer. In the response of next question 2 agreed that they can scan the general idea of the text easily, 11 students usually, 32 rarely and 10 said they can never scan the idea of the text easily. Next, 7 said that we can improve our vocabulary by additional reading, 35 said we can usually, 13 said they rarely while 1 said never. For next question 2 said that they can always express themselves in written language, 11 said that they usually, 32 said that they can rarely express and 10 said that they can never express themselves. And 3 students said that they can always write answers grammatically correct. 13 said they usually do so, 29 said they rarely do so and 10 said they can never do it so. Next 8 students said that they can guess/predict the meaning of the unknown words with reference to the context, 24 said that can usually guess/predict, 21 students said that they can rarely do so and 7 said that they can never do it. In the response of last question 31 students said that they always find difficult words while doing comprehension exercise, 19 said that they can usually do so, 7 said that they can rarely do while 3 said that they can never find.

\section{Conclusions}

By conducting tests in different universities the researcher discovered that the competency level of students at graduate level for both the universities were not satisfactory as far as the overall result of the students is concerned. Majority of the students were not been able to meet the objectives of the research i.e. Drawing inferences about the meanings of the words from context, Finding the answers of questions answered implicitly in the text, Drawing inferences of phrases/sentences from the context, Identifying writer's thoughts/ideas and to following the structure of passage. When the same students were given questionnaire they admitted that they face difficulty in reading comprehension and they also accepted that their competency level is low which can be increased through different ways like by conducting different activities, etc. 


\section{Discussion}

Mostly English language learner faces inconvenience in reading and understanding English text. The main reason is that limited understanding of sentence construction and limited number of vocabulary creates problem (Gunning, 2002). Poor word-level reading is one of the most common reasons because of which students struggle in understanding reading comprehension (Kilpatrick, 2015). In the view of Lankamp (1988) English reading proficiency is linked to their knowledge of the subject matter dealt within the text. The findings of the current study also support previous studies and reveal that the competency level of reading comprehension for students is not adequate. These issue could be solved by teaching the students modern techniques of skimming, scanning, predicting the meanings of the words/phrase in the light of context, make them able to adjust reading speed according to what they are reading, reducing the difficulty level of what they read, etc.

\section{Recommendations}

The following recommendation will prove to be useful for the improvement of reading comprehension;

1. For the development of reading comprehension of students teachers may apply a combination of methods according to the previous knowledge of the pupils.

2. The interest of the students may be developed by motivating them towards vocabulary building by providing them with interesting reading stuff. Reading skill should be taught with integration to other skills.

3. For student's understanding teachers may read all the words and sentences with correct stress and intonation in the class.

4. Teachers may encourage the students to understand the texts instead of cramming.

5. Teachers may illustrate students with easy techniques like: how to infer meaning from the context, etc.

\section{References}

Aebersold, J. A., \& Field, M. L. (1997). From reader to reading teacher. Cambridge: Cambridge University Press.

Alderson, C. J. (2002). Assessing Reading. The United Kingdom: Cambridge University.

Ashraf, R. M., \& Ahmad, I. S. (2003). "Promoting English language development and the reading program," Reading in a Foreign Language. 
15(2), October. Retrieved August 10, 2015, from http://www.nflrc.hawaii.rdu/rfl/October2003/mohdaraf.html

Chuenta, C. (2002). Reading materials for graduate students in administration (Unpublished master's thesis), Khon Kaen University, Khon Kaen, Thailand.

Ghizan, S. (2012). The effect of instructional reading software on developing English reading speed and comprehension for IT university students. Xlibris Corporation.

Graves, M. F., \& Ryder, R. J. (1998). Reading and learning in content areas. New York: Macmillan College Publishing Company.

Gunning, T. G. (2002). Assessing and correcting reading and writing difficulties. Boston: Allyn \& Bacon A Pearson Education Company.

Hayes, B. L. (1991). Effective strategies for teaching reading. Boston: Allyn and Bacon a Division of Simon \& Schuster, Inc.

International Journal of Applied Linguistics and English Literature (IJALEL: Vol. 3, No.3), 2014 by Editor (Paperback) - Lulu. (2014). Lulu.com. $\begin{array}{llll}\text { Retrieved } & 8 & \text { January } & \text { 2017, }\end{array}$ http://www.lulu.com/shop/editor/international-journal-of-appliedlinguistics-and-englishliterature-ijalel-vol-3-no32014/paperback/product-21533359.html

Israel, S. E., \& Duffy, G. G. (2014). Handbook of Research on Reading Comprehension. Routledge.

Keengwe, J. (2013). Cross-Cultural Considerations in the Education of Young Immigrant Learners. IGI Global.

Kilpatrick, D. A. (2015). Essentials of Assessing, Preventing, and Overcoming Reading Difficulties. John Wiley \& Sons.

Lankamp, R. E. (1988). A Study on the Effect of Terminology on L2 Reading Comprehension: Should Specialist Terms in Medical Texts be Avoided? (illustrated ed.). Rodopi. 
Lockyer, L. (2008). Handbook of Research on Learning Design and Learning Objects: Issues, Applications, and Technologies: Issues, Applications, and Technologies (reprint ed.). IGI Global.

Mc Lendon, N. C. (2008). The Effects of Teaching Critical Thinking and Reading Comprehension Strategies on Students' Writing in Developmental English in a Community College. ProQuest.

Nuttall, C. (2000). Teaching reading skills in a foreign language. Oxford: Macmillan.

Sarmini, S. E.-R. (2009). Exploring Bilingual Arab-American Students' Performance in Solving Mathematics Word Problems in Arabic and English. ProQuest LLC, 789 East Eisenhower Parkway, .

Shafaei, A., \& Nejati, M. (2009). Annals of Language and Learning: Proceedings of the 2009 International Online Language Conference (IOLC 2009). Universal-Publishers.

Singh, K. (2007). Quantitative Social Research Methods. SAGE Publications. 